\title{
The Economic Value of Corporate Eco-Efficiency
}

Citation for published version (APA):

Günster, N. K., Derwall, J. M. M., Bauer, R. M. M. J., \& Koedijk, C. G. (2006). The Economic Value of Corporate Eco-Efficiency. Finance.

Document status and date:

Published: 01/01/2006

Document Version:

Publisher's PDF, also known as Version of record

\section{Please check the document version of this publication:}

- A submitted manuscript is the version of the article upon submission and before peer-review. There can be important differences between the submitted version and the official published version of record.

People interested in the research are advised to contact the author for the final version of the publication, or visit the DOI to the publisher's website.

- The final author version and the galley proof are versions of the publication after peer review.

- The final published version features the final layout of the paper including the volume, issue and page numbers.

Link to publication

\footnotetext{
General rights rights.

- You may freely distribute the URL identifying the publication in the public portal. please follow below link for the End User Agreement:

www.umlib.nl/taverne-license

Take down policy

If you believe that this document breaches copyright please contact us at:

repository@maastrichtuniversity.nl

providing details and we will investigate your claim.
}

Copyright and moral rights for the publications made accessible in the public portal are retained by the authors and/or other copyright owners and it is a condition of accessing publications that users recognise and abide by the legal requirements associated with these

- Users may download and print one copy of any publication from the public portal for the purpose of private study or research.

- You may not further distribute the material or use it for any profit-making activity or commercial gain

If the publication is distributed under the terms of Article $25 \mathrm{fa}$ of the Dutch Copyright Act, indicated by the "Taverne" license above, 


\title{
The Economic Value of Corporate Eco-Efficiency
}

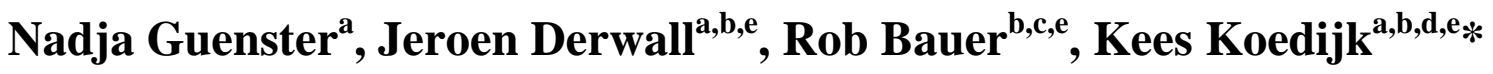 \\ a. RSM Erasmus University, Department of Financial Management \\ b. Maastricht University, Limburg Institute of Financial Economics (LIFE) \\ c. ABP Investments \\ d. Centre for Economic Policy Research (CEPR) \\ e. $\quad$ European Centre for Corporate Engagement (ECCE)
}

Date: August 2006

* Contact author:

Kees Koedijk

Department of Financial Management

RSM Erasmus University

PO BOX 1738

3000 DR Rotterdam

The Netherlands

Tel. $(+31) 104082790$

Fax: (+31) 104089017

E-mail address: ckoedijk@rsm.nl

\begin{abstract}
Acknowledgements:
We thank Innovest Strategic Value Advisors, Mark Bremmer, Roderick Molenaar and Vishal Jadnanansing for help with the data. We are grateful to Keith Ambachtsheer, Arnick Boons, Hans Dewachter, Mathijs van Dijk, Mark Flood, Abe de Jong, Lloyd Kurtz, Ronald Mahieu, Gerard Moerman, Arjen Mulder, Peter Roosenboom and Mike Russo, for economic and technical comments on the paper. The paper benefited from useful comments of participants of the 2005 Academy of Management Meetings, the 2005 FMA conference, and seminar participants at RSM Erasmus University and the University of Köln. We appreciate the editorial assistance of Sandra Sizer. We thank the U.S. Social Investment Forum and the Haas School of Business for awarding the paper the 2005 Moskowitz Prize and financial support. Finally, we thank The Foundation for Strategic Environmental Research (MISTRA) and Inquire Europe for research grants. All remaining errors are the sole responsibility of the authors. The views expressed in this paper are not necessarily shared by ABP Investments.
\end{abstract}




\title{
The Economic Value of Corporate Eco-Efficiency
}

\begin{abstract}
This study adds new insights to the long-running corporate environmental-financial performance debate by focusing on the concept of eco-efficiency. Using a new database of eco-efficiency ratings, we analyze the relation between eco-efficiency and financial performance from 1997 to 2004 . We report that eco-efficiency relates positively to operating performance and market value. Moreover, our results suggest that the market's valuation of environmental performance has been time variant, which may indicate that the market incorporates environmental information with a drift. Although environmental leaders initially did not sell at a premium relative to laggards, the valuation differential increased significantly over time. Our results have implications for company managers, who evidently do not have to overcome a tradeoff between eco-efficiency and financial performance, and for investors, who can exploit environmental information for investment decisions.
\end{abstract}

Keywords: Corporate Social Responsibility, Eco-Efficiency, Shareholder Value, Firm Value, Firm Operating Performance, Management Policies, Capital Markets

JEL Classification: G1, G3, M14 


\section{Introduction}

Fuelled by widely reported corporate environmental and social scandals, managers and shareholders are now showing heightened interest in the concept of corporate social responsibility (CSR). Some of the world's largest institutional asset managers, for example, those at CalPERS in the U.S., Universities Superannuation Scheme in the U.K., ABP and PGGM in the Netherlands, and AP7 in Sweden, are publicly demonstrating their commitment to investing in companies that are deemed socially, morally, and environmentally responsible.

In addition, several governmental organizations are considering the introduction of corporate reporting standards designed to accelerate these developments. For instance, an amendment to the 1995 Pension Act in the U.K., which was created in 2000, requires pension funds to disclose how they consider social and environmental issues.

In spite of greater acceptance of corporate social responsibility principles, there is a long-running debate on whether managers should incorporate CSR policies into their tactical and strategic decisions. One intriguing question has been the source of this great controversy: Can a firm do well while doing good? Most skeptics believe CSR is a vague construct that requires organizations to raise operating costs and to give up shareholder wealth (e.g., Walley and Whitehead, 1994). In contrast, scholars such as Fombrun et al. (2000), Porter and van der Linde (1995), and Spicer (1978) posit that corporate social responsibility initiatives can lead to reputational advantages, improvements in investors' trust in the company, more efficient use of resources, and new market opportunities, all of which could ultimately be perceived positively by capital markets.

Corporate environmental performance is considered an important component of the CSR construct, and its potential usefulness as a forward-looking measure of firm financial performance has gained acceptance, both in the literature and in practice. Although the assessment of the CSR-financial performance relationship relies heavily on qualitative data and subjective interpretation, the financial impact of environmental governance is easier to assess $a$ priori, particularly now that the law punishes negative environmental performance with concrete financial penalties more than ever before. For example, 15 years after the widely reported Exxon Valdez oil spill drama in Alaska, a federal judge recently imposed punitive damages of more than $\$ 4$ billion on the Exxon Mobil Corporation.

However, several scholars have stressed that the financial information content of environmental performance is not evident by itself. Among others, Hart and Ahuja (1996), King and Lenox (2002), and Russo and Fouts (1997) emphasize that companies can display 
environmental awareness through "end-of-pipe" pollution control, where companies clean up emissions subsequent to the production process, but that proactive pollution prevention techniques embedded in the firm's production processes are more likely to increase operating efficiency and profitability.

Building on these assertions, we focus on the concept of corporate eco-efficiency, a concept that reflects the environmental governance of the firm beyond that which is indicated by elementary environmental compliance and pollution control policies. Broadly, we can define eco-efficiency as creating more value with fewer environmental resources resulting in less environmental impact (for example, less pollution or natural resource exhaustion).

Using a comprehensive database of firm-level eco-efficiency scores produced by Innovest Strategic Value Advisors, we examine the relationship between corporate ecoefficiency and financial performance over the period 1997 to 2004 . The eco-efficiency data we use are made available on a monthly basis, allowing us to exploit statistical power. While the eco-efficiency scores we study are based on multidimensional research and are now monitored by some of the world's largest institutional investors, the data have not yet received much attention in the empirical literature.

By means of an accounting-based and a market-based measure, we capture different ways in which eco-efficiency influences financial performance. We use return on assets (ROA) which represents operating performance and profitability, and Tobin's $q(Q)$, which proxies for a company's valuation. $Q$ and ROA have several aspects in common but also differ in some important respects. ROA is based on firms' contemporaneous income, whereas Tobin's $q$ is a forward-looking measure that reflects the intangible value investors assign to a company. Since eco-efficiency is associated with both, tangible and intangible benefits, discrepancies might occur between its relation to ROA and $Q$.

The intangible nature of the benefits of eco-efficiency makes the task of valuing environmental governance complicated. Recent investment literature offers evidence that ecoefficiency is value-relevant but is incorporated slowly into a company's stock price. Derwall et al. (2005) compose two equity portfolios of stocks sorted on the eco-efficiency scores and assess their performance using elaborate performance attribution models. Their results suggest that companies labeled the most eco-efficient significantly outperformed their least ecoefficient counterparts by approximately 6 percent per annum over the period 1995-2003 after controlling for differences in risk, investment style and sector exposure. Their evidence seems to contradict the widely held view that assets are priced efficiently. The abnormal returns could 
be explained by a period of adjustment, where stocks of eco-efficient companies are initially undervalued and undergo a positive price correction subsequently. Accordingly, the upward trend in firm valuation generates anomalously high returns.

The Derwall et al. (2005) results have interesting research implications suggesting that the relation between environmental governance and firm valuation should be studied in a multi-period cross-sectional framework. If stock prices did not accurately incorporate environmental information then studies on the market valuation of corporate environmental management that implicitly assume market efficiency may have been time-specific and difficult to generalize. To our knowledge, this study is the first to investigate whether the market's valuation of environmental performance has strengthened over time by using a unique longitudinal sample of corporate eco-efficiency scores. We adopt a research design that allows for an exploration into both static and dynamic empirical relationships.

The paper is organized as follows. First, in the next section, we give an overview of prior related research, taking into consideration the financial variables of interest to this paper. This section also notes several limitations encountered in the literature and highlights the contribution of this study. Second, we outline several theoretical lines of reasoning pertaining to the link between corporate social (environmental) performance and financial performance. Third, we describe the database used for measuring corporate eco-efficiency. Finally, we discuss the empirical analysis and the results of our study.

\section{Literature Overview}

Researchers have long sought empirical evidence on the environmental-financial performance link. However, studies on CSR are well documented, but not well structured. Griffin and Mahon (1997) and Ullman (1985), among others, discuss this literature and point out that methodological inconsistencies across studies make most evidence incomparable and inconclusive. In this section, we review prior research while keeping in mind the financial variables central to this study: stock returns, firm value measured by Tobin's $q$, and return on assets.

\subsection{Prior Evidence}

The empirical literature relating the environmental component of CSR to stock performance separates into three subsets: event studies that explore the immediate effects of social or environmental performance proxies on short-term stock price variability; cross-sectional 
regression analyses that attempt to establish a longer-term relationship between CSR and stock returns; and portfolio studies that investigate the benefits of embedding CSR into investment decisions.

To date, event studies provide the best evidence of a link between environmental and stock market performance. This body of research, which includes studies by Hamilton (1995), Klassen and McLaughlin (1996), and Shane and Spicer (1983) suggests that although environmental pollution figures generally tend to have an influence on stock market performance, there is also an asymmetrical stock return sensitivity to environmental news. For example, Klassen and McLaughlin (1996) find evidence suggesting that a stock price increase following positive environmental information about the firm is less strong than a price decline in response to negative news.

A second group of studies uses regression or correlation analysis to explore long-term relationships between corporate environmental responsibility and stock returns. These studies provide mixed support for the notion of a relationship between environmental performance and shareholder value. Spicer (1978) reports that those companies in the U.S. pulp and paper industry that have better pollution control records have higher profitability figures and lower stock betas, but both Chen and Metcalf (1980) and Mahapatra (1984) fail to confirm the idea that pollution control initiatives are rewarded with improved stock performance. More consistent evidence pertains to markets outside the United States, for which Thomas (2001; U.K.) and Ziegler et al. (2002; Europe) document moderate evidence of a positive relationship between environmental performance and stock returns. Portfolio research typically involves a comparison of average risk-adjusted returns between two or more mutually exclusive portfolios. These portfolios are constructed using a company characteristic as a discriminating factor. Portfolios are usually evaluated by using a performance attribution model that controls for common intervening factors known to influence portfolio performance. Despite the popularity of this approach in the mainstream asset pricing literature (e.g., Fama and French, 1993), remarkably little research has applied environmental firm characteristics as a discerning variable. Among the few exceptions, research by Cohen et al. (1997) suggests that there is neither a premium nor a penalty for investing in environmental leader companies. On the other hand, White (1996) finds that his "green" portfolio provides a significantly positive market-risk adjusted return, while "brown" and "oatmeal" portfolios do not. Recent research by Derwall et al. (2005), who use modern performance evaluation techniques, suggests that eco-efficient 
companies jointly provide anomalously positive equity returns relative to their less-eco efficient peers over the period 1995-2003.

A relatively recent strand of research addresses the evidence on potential links between environmental performance and firm value. Generally, the evidence is uniform and points to a positive and significant relationship between environmental management policies and Tobin's $q$. Dowell et al. (2000) separate multinational firms in their U.S. sample into three groups: firms that default internationally to (less stringent) local environmental standards; companies that apply U.S. environmental standards on an international scale; and firms that adopt more stringent standards than those required by U.S. law. Their results suggest that firms that adopt higher, more stringent environmental criteria have a higher firm valuation than those that use less stringent ones.

These findings are consistent with Konar and Cohen (2001), who suggest that firms that are disposing of relatively smaller amounts of toxic chemicals, and those that are confronted with fewer or no environmental lawsuits, tend to have a higher $Q$. King and Lenox (2002) further expand previous research by disentangling the emissions of a large number of U.S. firms into sub-aggregates. The important conclusion from their work is that waste prevention and future firm value are positively associated, but that pollution reduction efforts by other means, such as "end-of-pipe" pollution treatment, do not affect Tobin's $q$.

Another massive body of research relies on operating performance measures, predominantly using accounting data. ${ }^{1}$ Not surprisingly, the results from this research are somewhat dependent on the choice of operating performance measure. A few empirical studies are of particular concern to our work. Considerable interest has been shown in the company's return on assets as a dependent variable, primarily because ROA is one of the broadest measures of firm operating performance. For example, Freedman and Jaggi (1988) investigate the relation between environmental pollution disclosure and several accounting-based performance indicators but find little evidence to support the conjecture that there is a clear-cut and significant association. However, McGuire et al. (1988) show that, contrary to alternative measures in their study, ROA does correlate with their corporate social performance index. Russo and Fouts (1997) complement previous work, suggesting that environmental performance is positively connected with ROA but also that this association is more pronounced for high-growth industries. Hart and Ahuja (1996) and Waddock and Graves

\footnotetext{
${ }^{1}$ For a detailed overview the reader is referred to Griffin and Mahon (1997) and Ullman (1985).
} 
(1997) also report that several financial measures, including ROA, relate significantly to environmental performance indicators, but express some doubts regarding the direction of causality. In a more recent study, King and Lennox (2002) suggest that pollution prevention, but not pollution treatment, causes higher return on assets.

\subsection{Contribution to Existing Literature}

While the research up to this point seems overwhelming at first glance, a substantial part of the evidence should be interpreted with caution. Our goal in this paper is to overcome several methodological limitations that are often encountered in the empirical literature. Broadly, our enhancements pertain to the following areas.

First, we address the problem of choosing an appropriate proxy for environmental performance. Corporate social (environmental) responsibility is a broad construct that can only be assessed with multidimensional indicators. As also suggested by Waddock and Graves (1997), the majority of related literature relies on measures that either lack sufficient depth and detail or, alternatively, are too noisy to be fully capable of measuring corporate social or environmental performance. In addition, as underscored by Konar and Cohen (2001), most previous research analyzes data that only point towards historical performance. In contrast, our study builds on the concept of eco-efficiency, which is a more strictly defined construct and can be quantified by using Innovest's eco-efficiency rating methodology. As we explain, the rating is not only intended to reflect historical environmental performance, but also to identify future environmental risks and opportunities.

Our second contribution concerns the choice and interpretation of financial performance criteria. We first use accounting-based and a market-based measures to assess the different pathways leading environmental management to financial performance. Using return on assets, we capture the association between environmental and operating performance. Via Tobin's $q(Q)$, we capture the value investors assign to environmental policies.

Moreover, we then extend earlier studies that implicitly infer a static relation between environmental management and performance based on market value measures. While Dowell et al. (2000), King and Lennox (2002), and Konar and Cohen (2001) suggest that environmental governance is positively related to market value measures of performance, recent evidence casts doubt on whether environmental information is valued accurately. Derwall et al. (2005) point to an anomalously positive stock return differential between environmental leaders and laggards, suggesting that environmental information is incorporated 
slowly into stock prices. Their results motivate us to analyze whether the relation between environmental performance and Tobin's $q$ has strengthened over time. The environmental database we study is unique in that it covers monthly environmental performance ratings for more than eight years. Thus, it is an excellent means for testing time-varying relationships. Using a variant of the two-step modeling approach introduced by Fama and MacBeth (1973), we are able to exploit the richness of information contained by both cross-sectional and timeseries dimensions of the data.

\section{Theoretical Debates and Hypotheses}

For several decades, the academic community has postulated models and hypotheses that relate corporate social and environmental responsibility to financial performance, mostly with the intention to provide a framework that aligns CSR with shareholder value creation. Despite the growing academic attention on the CSR-financial performance relationship, management scientists and financial economists have developed their ideas in this area almost autonomously. Corporate management theories up to this point discuss many benefits to CSR, but leave unexplained questions that are critically relevant to shareholders of socially and environmentally responsible companies. Modern investment theories fill that gap. In this section, we introduce and test hypotheses that combine management and financial theories. Both theories are critical for understanding how firms' environmental management relates to financial performance.

\subsection{Management Theories}

The CSR-financial performance relationship is the source of considerable debate. Theories in the management literature are far from uniform and, as pointed out by Griffin and Mahon (1997), more than 25 years of empirical research has been unable to overcome long-lasting theoretical divides.

The roots of the debates go back decades. During the 1960s, the concepts of corporate social responsibility and socially responsible investing were gaining momentum. However, opponents of CSR quite forcefully questioned the validity of CSR in the context of what they believed is the purpose of the firm: maximizing shareholder wealth. In general, opponents of the concept of CSR raise two critical points: 
- CSR is far from well defined. A view shared by many skeptics, including Friedman (1962), is that managers are unable to determine what the social responsibility of their company is. Many managers believe that the only responsibility of the firm is to engage in profitable activities. Shareholders themselves are capable of deciding whether their stock income sufficiently represents social awareness.

CSR is expensive and decreases shareholder value. At least partially because of the problem of determining the social responsibility of businesses, a common criticism of CSR cites the financial dangers of adopting corporate social responsibility principles. Several critics stress that CSR initiatives inherently demand significant portions of a company's financial resources, but the potential financial benefits of such initiatives are mostly in the distant future, if these benefits are evident at all (e.g., Henderson, 2002; Walley and Whitehead, 1994).

Briefly, the main concern expressed by CSR skeptics is that the costs associated with corporate social performance improvements are likely to outweigh the financial benefits, which makes CSR inconsistent with the principles of shareholder wealth maximization.

In contrast, a sizable number of CSR proponents have put forward a long list of the advantages to corporate social responsibility. Their reasoning is that organizations can generate significant goodwill and new market opportunities by displaying social and environmental awareness (e.g., Fombrun et al., 2000; Hart and Ahuja, 1996; Porter and Van der Linde, 1995; Russo and Fouts, 1997). However, there is a growing belief that the economic benefits depend on the nature of environmental performance. More and more often, researchers argue that the advantages resulting from social and environmental compliance with regulatory requirements are not a primary source of competitive advantage. For example, the mere fact of environmental compliance hardly allows a company to distinguish itself from its competitors, because most intra-industry peers are affected by compliance in a similar way. As pointed out by Dowell et al. (2000), Hart and Ahuja (1996), and Russo and Fouts (1997), real benefits to organizations are likely to come from more rigorous (i.e., proactive) forms of environmental performance that require both changes in production and manufacturing processes and a forward-looking management style. Hillman and Keim (2001) add that CSR initiatives can pay off, as long as these efforts are in the interest of the company's primary stakeholders.

Conditional on these lines of reasoning, specific arguments in favor of CSR include: 
- CSR is associated with reputational benefits. Several scholars suggest that adopting corporate social responsibility policies may lead to improvements in the firm's image (e.g., Davis, 1973). Because the firm's social performance record can proxy for labor conditions, socially responsible companies gain a competitive advantage by improving their ability to attract high-quality employees. Empirical evidence by Turban and Greening (1996) strongly supports this line of reasoning. Apart from human-resource benefits, other researchers, for instance, Vandermerwe and Oliff (1990), and Russo and Fouts (1997), mention the possibility that reputational advantages result in sales benefits, because customers may be sensitive to social issues. Similarly, reputational increases may affect relationships with potential suppliers and lenders.

- CSR can also serve as a proxy for management skills. Alexander and Buchholz (1978) and Bowman and Haire (1975) suggest that corporate social and environmental performance reflects management quality. A structural and dedicated CSR policy might inherently require commitment to CSR among and between all levels of the firm as well as a forward-thinking, long-term-oriented management (Shrivastava (1995)).

- CSR may also reflect (technological) innovativeness. For example, Porter and van der Linde (1995) argue that poor environmental performance is a sign of the firm's operational inefficiency, which ultimately leads to competitive disadvantages. In addition, the resource-based view towards environmental governance, as outlined by Russo and Fouts (1997), says that a proactive environmental policy within the firm ultimately requires a structural change in production and service delivery processes. This redesign involves the development, acquisition, and implementation of new technologies and may lead to economic advantages vis-à-vis competitors.

In fact, the resource-based view suggests that only pro-active environmental governance is a source of financial benefits, which will be unique to the firm and difficult to obtain by competitors. Since eco-efficiency closely coincides with the resource-based view in that it represents pro-active environmental management, we arrive at the following hypothesis:

$H_{1}$ : Eco-efficiency relates positively to operating performance, ceteris paribus. 


\subsection{Financial Theories}

Now, more than ever before, financial-market participants have been paying attention to CSR. Institutional investors are demonstrating their interest in the concepts CSR and socially responsible investing (SRI) as a means of fulfilling their social and financial obligations. Recent estimates by the Social Investment Forum (2003) suggest that the market for socially responsible investments currently covers approximately 12 percent of the market as a whole.

Analogous to these developments, researchers, starting with Moskowitz (1972), have put forward theoretical frameworks that either support or reject the validity of CSR from an investor perspective. These frameworks rely on established asset pricing theories which center on the risk-return paradigm.

The risk-return paradigm is important because it highlights that managerial perspectives towards CSR are only one part of the story. Although there is a tendency among management scholars to believe that firms are doing well by engaging in activities that increase their (intangible) value, financial theories add important insights on benefits from such activities in terms of risk-adjusted returns to stockholders. Whether investors benefit from holding stocks of socially responsible companies depends on how financial markets value CSR.

Hamilton, Jo, and, Statman (1993) note that financial markets may respond to corporate social responsibility information in three different ways:

In scenario one, the market does not value corporate social responsibility. Investors do not tie better social or environmental performance to lower risk. Consequently, the expected stock returns of CSR leaders are no different from those of laggards, all else equal, and firm value is independent of environmental governance. This scenario would be supported empirically by evidence that a relation between CSR and market-based measures of firm value is not statistically significant. This scenario can apply to CSR as well as any of its subsets. When focused on the concept of ecoefficiency, the hypothesis that follows from this scenario can be stated as:

$H_{2 a}$ : Eco-efficiency is not associated with firm value, ceteris paribus.

Contrary to scenario one, the second scenario predicts that investors do value CSR. As suggested by Narver (1971), Shane and Spicer (1983) and Spicer (1978), firms with a strong social or environmental performance record might be regarded as less 
risky investments compared to poor environmental performers. In the risk-return framework, the notion that social and environmental leaders are less risky investments than laggards implies that investors demand a lower return on these firms' stocks. Because investors assign a lower discount rate to expected future cash flows of socially responsive companies, these firms have a higher value. We note that if capital markets incorporate information related to CSR efficiently, we can assume that expected returns on stocks compensate investors fairly for the associated risk, and that risk-adjusted stock returns are consistent with an equilibrium setting. When the focus is on the economic significance of corporate eco-efficiency, the hypothesis consistent with the second scenario is stated as:

$H_{2 b}$ : Eco-efficiency is positively associated with firm value, ceteris paribus.

Scenario three revolves around a disequilibrium. This scenario raises the possibility that the paradigm is violated in practice and suggests that the market does not price CSR efficiently. Investors may find it complicated to value the benefits or costs associated with environmental governance, particularly intangible ones. Whether environmental information is slowly impounded into stock prices has important implications for both firm value and stock returns. Under the previous scenario, the expected returns on environmental leaders firms, all else equal, should be lower than those of environmental laggards. In the third case, however, stocks of socially responsible companies can be initially undervalued (overvalued) relative to those of less socially responsible companies and ultimately produce higher (lower) riskadjusted returns. Recent empirical evidence by Derwall et al. (2005) indicates that eco-efficient stock portfolios outperformed their least eco-efficient counterparts by more than is suggested by investment risk, supporting an undervaluation hypothesis. The Derwall et al. (2005) study motivates the following hypothesis:

$H_{2 c}:$ The valuation differential between the most eco-efficient firms and the least ecoefficient firms increases over time, ceteris paribus. 
Collecting evidence in support of this hypothesis requires that we analyze the market's valuation of firms' CSR characteristics over time. The unique longitudinal dimension of the environmental data in this study satisfies that condition.

\section{Data}

\subsection{Eco-Efficiency Data}

Among both managers and scholars, there is no consensus as to precisely what constitutes the social or environmental responsibility of the firm. Traditional proxies for environmental performance, such as environmental reports by third-party organizations, typically rely on news concerning absolute pollution levels. However, these indicators of environmental responsibility address merely a single dimension of a company's environmental performance and usually reflect historical environmental events.

We focus on eco-efficiency. As noted earlier, we define a firm's eco-efficiency as the ability to create more value while using fewer environmental resources, such as water, air, oil, coal and other limited natural endowments. Dowell et al. (2000) interpret eco-efficiency as the ability of companies to minimize pollution by improving the production and manufacturing process. This form of environmental responsibility represents proactive environmental management, one which concentrates on good environmental performance from changes in operational efficiency, rather than by adopting standards for pollution control at the "end of the pipe".

Eco-efficiency usually measures the environmental performance of a firm in a relative sense. To understand the difference between absolute and relative environmental performance, consider, for example, firms that operate in environmentally sensitive industries such as mining, energy, or chemicals. In absolute terms, these firms are usually regarded as poor environmental performers. However, at the intra-industry level, firms facing the same environmental challenges can still do well relative to competitors, and can benefit from this financially.

We explore empirical relationships between eco-efficiency and several dimensions of corporate financial performance. To do so, we use eco-efficiency scores developed by Innovest Strategic Value Advisors. Since the Innovest data have received little attention in previous research, by using Innovest's data we can provide new evidence.

One of the main strengths of this database is its comprehensiveness. Using over 20 information sources, both quantitative and qualitative in nature, Innovest's analysts evaluate a 
company relative to its industry peers via an analytical matrix. Companies are evaluated by more than 60 criteria, which jointly constitute the final rating. For each of these factors, all companies receive a (sub)score. As these variables are not considered equally important in the overall assessment of eco-efficiency, each factor is weighted differently. For example, Innovest analysts consider a firm's environmental product development as more important than certification by a third party that is devoted to promoting environmental awareness. The final numerical rating analysts assign to a company is converted into a relative score based on the total spread of scores in the sector to which the firm belongs.

The eco-efficiency score reflects environmental performance in five fundamental areas. The first broad area covers historical liabilities, which concern the risks (and opportunities) a firm faces in consequence of past environmental behavior. Among other things, this category covers superfund liabilities, state and hazardous waste sites, and toxic torts. A second component represents contemporaneous operating risk, addressing risk exposures from events that are more recent. This category includes, for example, toxic emissions, product risk liabilities, waste discharges, and supply-chain management risk. The third area, which can be labeled "sustainability and eco-efficiency risk," pertains to the weakening of a firm's material sources of long-term profitability and competitiveness, and the potential future risks initiated by this development. This area spans energy intensity, energy efficiency, the durability and recyclability of the product life cycle, but also the extent to which companies are exposed to changes in consumer values. The fourth area covered by the score concerns managerial risk efficiency. This category represents the ability of the company to manage environmental risks successfully, as can be witnessed from, e.g., the quality of supply chain management, environmental audit/accounting capacity, the strength of environmental management systems, training capacity. The last dimension involves business prospects resulting from ecoefficiency, such as the degree to which businesses can reap future competitive advantages from environmentally driven market trends and profit opportunities provided that the company's management has well-developed eco-efficiency policies.

From this brief overview, it becomes apparent that Innovest's eco-efficiency measure is intended to embody both ex post (i.e., historical and current) and ex ante (i.e., forward-looking) dimensions of corporate eco-efficiency.

In this paper, we consider firms listed on the U.S. stock markets. As we also use various financial data, we match the Innovest database to the CRSP U.S. stock database and to the Compustat U.S. Research database. We match by ticker, company name, and CUSIP number. 
The resulting data set is survivor-bias-free in the sense that it includes not only firms that were covered by Innovest recently, but also those which disappeared over time, for instance, due to merger or bankruptcy. Further details on the financial data will be given in the appropriate sections.

TABLE 1

\section{Summary Statistics on Eco-Efficiency Scores}

The table summarizes the mean eco-efficiency and median scores, the standard deviation of the score, and the number of firms with a given score, observed at the end of 1996, 1998, 2000, 2002, and September 2004, respectively. The Change column gives changes in these values over the beginning and the end of the sample period.

\begin{tabular}{|c|c|c|c|c|c|c|}
\hline & Dec.-96 & Dec. -98 & Dec. -00 & Dec.-02 & Sept.-04 & $\begin{array}{c}\text { Change } \\
\text { (1996-2004) }\end{array}$ \\
\hline \multicolumn{7}{|c|}{ Eco-Efficiency Ratings } \\
\hline Mean Rating & 3.04 & 2.82 & 2.71 & 2.49 & 2.30 & -0.74 \\
\hline Median Rating & 3 & 3 & 3 & 2 & 2 & 1.00 \\
\hline Standard Deviation & 1.80 & 1.94 & 1.88 & 1.83 & 1.68 & 0.03 \\
\hline \multicolumn{7}{|c|}{ Number of Companies } \\
\hline Eco-Efficiency $=0$ & 19 & 46 & 79 & 65 & 71 & 52 \\
\hline Eco-Efficiency $=1$ & 13 & 39 & 54 & 99 & 133 & 120 \\
\hline Eco-Efficiency $=2$ & 28 & 39 & 63 & 66 & 109 & 81 \\
\hline Eco-Efficiency $=3$ & 28 & 43 & 102 & 65 & 70 & 42 \\
\hline Eco-Efficiency $=4$ & 27 & 46 & 64 & 62 & 67 & 40 \\
\hline Eco-Efficiency $=5$ & 27 & 37 & 45 & 43 & 49 & 22 \\
\hline Eco-Efficiency $=6$ & 12 & 28 & 42 & 30 & 20 & 8 \\
\hline Total & 154 & 278 & 449 & 430 & 519 & 365 \\
\hline
\end{tabular}

We convert Innovest's seven non-numerical ratings into numerical eco-efficiency scores, where the highest-ranked firms receive a rating equal to six and lowest-ranked firms receive a rating of zero.

Table 1 shows some statistics on the eco-efficiency scores over time. These statistics are merely descriptive and serve as some background for the analyses that follow.

The table shows results for five particular dates. We note that the last date covered by Table 1 is September 2004, because the financial data are reported on a quarterly basis (i.e., we 
regress fourth-quarter financial measures on eco-efficiency scores that are dated September). Over the period 1996-2004, the average rating decreases from 3.04 to 2.30 . The median rating decreases from 3 to 2 . The standard deviation varies only mildly over time.

The table also reports the frequency of the eco-efficiency score broken up into seven categories. Statistics on the number of firms within each rating category explain the decrease in average eco-efficiency rating. The number of firms that receive an eco-efficiency score below 3 increases more strongly compared to the number of firms that have a score of 4 or higher.

The number of firms in the sample increases considerably over time. Our data set includes scores for 154 companies at the end of December 1996 and 519 firms at the end of September 2004.

\subsection{Financial Data}

To accomplish our objective of investigating the association between eco-efficiency and several dimensions of corporate financial performance, we first analyze the connection between eco-efficiency and operating performance. Our primary interest is in a broad measure of operating performance that addresses both profitability and efficiency. Inspired by Barber and Lyon (1996), we measure operating performance by the company's return on assets. Our set of control variables is similar to Waddock and Graves (1997). We control for the influence of firm size and the firm's riskiness. We measure size by the firm's total assets and by total sales. The debt-to-asset ratio represents risk. We use data from Compustat to construct all variables.

Next, we turn our attention to the role of eco-efficiency in firm valuation, using the Tobin's $q$ measure. Following Kaplan and Zingales (1997), we compute $Q$ as the market value of assets divided by the book value of assets. The market value of assets is defined as the sum of the book value of assets and the market value of common stock outstanding minus the sum of the book value of common stock and balance sheet deferred taxes. Although there are more sophisticated approaches to computing $Q$, we use the most efficient approximation to ensure sufficient data availability throughout our sample period. Further, as shown by Perfect and Wiles (1994), and by Chung and Pruitt (1994), this proxy for $Q$ is highly correlated with estimates that are more complex.

Our Tobin's $q$ analysis accounts for potentially confounding influences. Because researchers such as Hirsch (1991) show that recent sales growth is positively related to company valuation, we include past two-year sales growth as a control variable. Furthermore, 
related work, including Dowell et al. (2000), King and Lenox (2002), and Konar and Cohen (2001), suggests that firm value is positively related to $R \& D$ expenses. To parse out this relationship, our control set contains research and development expenses scaled by sales as an additional explanatory variable. To condition on differences in operating performance we use return on assets (ROA). Following Gompers et al. (2003), we use the logarithm of the book value of assets to account for differences in firm size. We also include firm age. As an approximation of the firm's age, we compute the difference between the first trading day and the respective date of the analysis. Since the database "Exshare", from which we retrieve the first trading days, was established in November 1984, we lack information before 1984. If firms were founded before this date, we still assume that founding occurred in 1984.

Finally, we consider a dummy variable that is equal to unity if the firm is listed on the Nasdaq exchange and zero otherwise. The dummy controls for atypically high Tobin's $q$ values of Nasdaq firms that may have occurred during the stock market hype of the late nineties. We construct all variables other than firm age using data from Compustat.

TABLE 2

Summary Statistics on Tobin's $q$ and ROA

Cross-sectional statistics are reported for the first quarter of 1997, 1999, 2001, 2003 and the last quarter of 2004 .

\begin{tabular}{lccccc}
\hline & $1997 \mathrm{Q} 1$ & $1999 \mathrm{Q} 1$ & $2001 \mathrm{Q} 1$ & $2003 \mathrm{Q} 1$ & $2004 \mathrm{Q} 4$ \\
\hline Tobin's $q(Q)$ & & & & & \\
& & & & & \\
Mean $Q$ & 1.73 & 2.30 & 2.22 & 1.75 & 1.99 \\
Median $Q$ & 1.46 & 1.55 & 1.56 & 1.30 & 1.61 \\
Standard Deviation & 1.00 & 1.87 & 1.68 & 1.16 & 1.23 \\
Skewness & 2.91 & 2.41 & 2.30 & 2.68 & 2.68 \\
Kurtosis & 14.83 & 9.21 & 9.50 & 13.29 & 13.36 \\
& & & & & \\
Return on Assets (ROA) & & & & & \\
& & & & & \\
Mean ROA & 0.04 & 0.04 & 0.04 & 0.03 & 0.04 \\
Median ROA & 0.04 & 0.04 & 0.03 & 0.03 & 0.03 \\
Standard Deviation & 0.02 & 0.02 & 0.03 & 0.02 & 0.02 \\
Skewness & 0.08 & 0.51 & 0.38 & 0.89 & 0.59 \\
Kurtosis & 5.60 & 3.66 & 5.90 & 6.42 & 5.16 \\
& & & & & \\
\hline
\end{tabular}


To show the distribution of ROA and $Q$, Table 2 reports descriptive statistics pertaining to five specific dates. The distribution of ROA is quite symmetric. Median and mean values for ROA do not display a large discrepancy, being similar in value and time invariant. As for the distribution of Tobin's $q$, we can see that there is some non-normality in the data. $Q$ has a distribution that is peaked and leptokurtic, as indicated by the high values for skewness and kurtosis. Arguably, the stock market fad of 2000 plays an important role in explaining the long right tail in the $Q$ data. Further, we observe differences in the cross-sectional median $Q$ and the mean $Q$ over time. The median values for Tobin's $q$ remain relatively stable but mean values are much higher during the technology boom and bust period. We alleviate potential problems associated with non-normality by doing robustness tests after having industry-adjusted, taken in logs, and trimmed the data, respectively. The dummy variable for companies listed on the Nasdaq Stock Exchange captures potentially extreme Tobin's $q$ values during the technology bubble.

\section{Empirical Analysis}

\subsection{Eco-Efficiency and Return on Assets}

In order to analyze the relation between eco-efficiency and operating performance, we follow the multivariate model of Waddock and Graves (1997). Cross-sectional analysis is most suitable for testing our hypothesis. ${ }^{2}$ Since our data are longitudinal in nature, periodical regressions can be performed. We estimate the following cross-sectional models quarter by quarter from 1997 to 2004 :

$$
\begin{aligned}
& R O A_{i t}=\alpha_{i}+\beta_{1} \text { Eco-Efficiency }_{i t}+\gamma_{i t} X_{i t}+\varepsilon_{i t}, \\
& R O A_{i t}=\alpha_{i}+\beta_{0} \text { High Eco-Efficiency } y_{i t}+\beta_{1} \text { Low Eco-Efficiency } y_{i t}+\gamma_{i t} X_{i t}+\varepsilon_{i t},
\end{aligned}
$$

where $\mathrm{ROA}_{\mathrm{it}}$ denotes return on assets. We consider modeling both ROA and the firm's ROA relative to the industry median ROA. Eco-Efficiency it in model (1) represents the firm's ecoefficiency score. This model, therefore, assumes linear relations. To account for the possibility of nonlinearity in the relation between eco-efficiency and our financial measures we develop an alternative model. In specification (2), we replace the absolute eco-efficiency score with two dummy variables that specify whether firm $\mathrm{i}$ is the most or the least eco-efficient. High Eco-

\footnotetext{
${ }^{2}$ At first glance, a plausible alternative approach could be a pooled model that allows for fixed effects and timespecific events. However, we rejected this setup due to a lack of time variation in firms' eco-efficiency scores.
} 
Efficiency $_{i t}$ (Low Eco-Efficiency it $_{\text {) }}$ is equal to one if firm i is rated five or six (zero or one) at $t$, and zero otherwise. $X_{i t}$ is a vector of control variables and $\gamma$ is a vector of coefficients. We allow for permutations of the regressors. Candidate control variables include the firm's size measured either by total assets or by total sales, and the debt-to-asset ratio. Using a variant of the Fama-MacBeth (1973) method, we compute time-series averages of the 32 cross-sectional regression coefficients. We calculate corresponding $t$-statistics based on standard errors from the 32 parameter estimates which we obtain for each variable.

Table 3 reports the time-series average coefficients and corresponding $t$-statistics. We note that the coefficient estimates for all control variables are consistent with those reported by Waddock and Graves (1997). With the exception of total sales, they are all statistically significant at the usual cut-off levels.

In panel A of Table 3, we report coefficients on the eco-efficiency score. EcoEfficiency it has a coefficient that is positive and significant at the 1 percent level. All specifications indicate that the positive relation between eco-efficiency and ROA is robust to changes in the set of dependent and control variables. The results of replacing Eco-Efficiency with High Eco-Efficiency ${ }_{i t}$ and Low Eco-Efficiency ${ }_{i t}$ are shown in Panel B of Table 3. There is weak evidence of an asymmetry in the relation between eco-efficiency and operating performance. Our estimates suggest that the underperformance of the least eco-efficient firms (relative to the reference group) is almost twice as large as the outperformance of the most ecoefficient companies. Moreover, the operational underperformance associated with environmental laggards is significant at the 1 percent level in all specifications. The outperformance of environmental leaders is marginally significant.

From an economic perspective, eco-efficiency relates sizably to operating performance. The increase in absolute ROA resulting from a one-point rise in eco-efficiency ranking is estimated at 0.09 percent, ceteris paribus, which is about 2.2 percent of the sample average ROA we observe in Table 2. To get an impression of the asymmetrical influence of ecoefficiency on operating performance, we can estimate how much loss in ROA a firm in the reference group (category 2, 3 and 4) would prevent by avoiding a low eco-efficiency ranking. Panel B points out that the loss prevention amounts to about 0.32 percent, which is 8.4 percent of the average ROA. The gain a firm can achieve by obtaining a high eco-efficiency rating is 0.14 percent, which is about 3.6 percent of the average ROA.

In support of $\mathrm{H}_{1}$ we find a positive relation between eco-efficiency and operating performance. Our evidence also suggests that the relation is asymmetric, for which we offer 


\section{TABLE 3}

\section{Eco-Efficiency and Return on Assets (ROA): Fama-MacBeth (1973) Regressions}

The table reports the Fama-MacBeth (1973) time-series mean coefficient and the corresponding $t$-statistic (in parentheses). Note: Low Eco-Efficiency $=1$ if firm ranked $\leq$ 1. High-Eco-Efficiency $=1$ if firm ranked $\geq 5$. To compute the difference between the coefficients, we subtract the Low Eco-Efficiency coefficient from the coefficient of the High Eco-Efficiency dummy. The coefficients are multiplied by 100. Ind-Adj. ROA is industry-adjusted return on assets. The sample period is 1997-Q1 - 2004-Q4. Significance at the $1 \%, 5 \%$, and $10 \%$ level is indicated by ${ }^{* * *},{ }^{* *}$, and ${ }^{*}$, respectively.

\begin{tabular}{|c|c|c|c|c|c|c|c|c|}
\hline & \multicolumn{8}{|c|}{ Fama-MacBeth Time-series Average Coefficients } \\
\hline & \multicolumn{4}{|c|}{ Panel A: Equation (1) } & \multicolumn{4}{|c|}{ Panel B: Equation (2) } \\
\hline & ROA & Ind.Adj. ROA & ROA & Ind.Adj. ROA & ROA & Ind.Adj. ROA & ROA & Ind.Adj. ROA \\
\hline Intercept & $\begin{array}{l}4.19^{* * *} \\
(26.70)\end{array}$ & $\begin{array}{l}0.20^{* * *} \\
(3.76)\end{array}$ & $\begin{array}{l}4.17^{* * *} \\
(26.31)\end{array}$ & $\begin{array}{l}0.20^{* * *} \\
(3.72)\end{array}$ & $\begin{array}{l}4.50^{* * *} \\
(27.42)\end{array}$ & $\begin{array}{l}0.51^{* * *} \\
(8.61)\end{array}$ & $\begin{array}{l}4.45^{* * *} \\
(26.50)\end{array}$ & $\begin{array}{l}0.50^{* * *} \\
(8.24)\end{array}$ \\
\hline Eco-Efficiency & $\begin{array}{l}0.09^{* * *} \\
(8.05)\end{array}$ & $\begin{array}{l}0.09^{* * *} \\
(6.69)\end{array}$ & $\begin{array}{l}0.08^{* * *} \\
(7.22)\end{array}$ & $\begin{array}{l}0.08^{* * *} \\
(6.55)\end{array}$ & & & & \\
\hline Low Eco-Efficiency & & & & & $\begin{array}{l}-0.34^{* * *} \\
(-7.45)\end{array}$ & $\begin{array}{l}-0.32^{* * *} \\
(-6.49)\end{array}$ & $\begin{array}{l}-0.31^{* * *} \\
(-6.63)\end{array}$ & $\begin{array}{l}-0.31^{* * *} \\
(-6.33)\end{array}$ \\
\hline High Eco-Efficiency & & & & & $\begin{array}{l}0.19^{* *} \\
(2.60)\end{array}$ & $\begin{array}{l}0.11^{*} \\
(1.75)\end{array}$ & $\begin{array}{l}0.15^{* *} \\
(2.20)\end{array}$ & $\begin{array}{c}0.10 \\
(1.64)\end{array}$ \\
\hline \multicolumn{2}{|c|}{ Difference: High-Low Eco-Efficiency } & & & & $\begin{array}{l}0.52^{* * *} \\
(9.05)\end{array}$ & $\begin{array}{l}0.43^{* * *} \\
(6.98)\end{array}$ & $\begin{array}{l}0.46^{* * *} \\
(7.92)\end{array}$ & $\begin{array}{l}0.41^{* * *} \\
(6.86)\end{array}$ \\
\hline \multicolumn{9}{|l|}{ Control variables: } \\
\hline Book Value of Assets & $\begin{array}{c}-4.74 \mathrm{E}^{-6 * * *} \\
(-11.81)\end{array}$ & $\begin{array}{c}-2.23 \mathrm{E}^{-6^{* * * *}} \\
(-4.98)\end{array}$ & & & $\begin{array}{c}-4.64 \mathrm{E}^{-6 * * *} \\
(-10.90)\end{array}$ & $\begin{array}{c}-2.17 \mathrm{E}^{-6 * * *} \\
(-4.89)\end{array}$ & & \\
\hline Debt/Assets & $\begin{array}{l}-3.17^{* * *} \\
(-6.45)\end{array}$ & $\begin{array}{l}-1.86^{* * *} \\
(-5.83)\end{array}$ & $\begin{array}{l}-3.27^{* * *} \\
(-6.77)\end{array}$ & $\begin{array}{l}-1.91^{* * *} \\
(-5.88)\end{array}$ & $\begin{array}{l}-3.20^{* * *} \\
(-6.38)\end{array}$ & $\begin{array}{l}-1.89^{* * *} \\
(-5.74)\end{array}$ & $\begin{array}{l}-3.31^{* * *} \\
(-6.69)\end{array}$ & $\begin{array}{l}-1.94^{* * *} \\
(-5.80)\end{array}$ \\
\hline Sales & & & $\begin{array}{c}-5.32 \mathrm{E}^{-6} \\
(-1.54) \\
\end{array}$ & $\begin{array}{c}-7.39 \mathrm{E}^{-6 *} \\
(-2.01) \\
\end{array}$ & & & $\begin{array}{c}-4.70 \mathrm{E}^{-6} \\
(-1.30) \\
\end{array}$ & $\begin{array}{c}-6.25 \mathrm{E}^{-6} \\
(-1.69) \\
\end{array}$ \\
\hline
\end{tabular}


two explanations. First, although our ratings are converted into numbers, they have no real unit of measurement. Caveats associated with ordinal data could prevent us from accurately measuring differences in eco-efficiency and induce false suggestions of an asymmetry. A second explanation is that the negative financial impact resulting from poor environmental governance is mostly tangible of nature and therefore visibly reflected in operating performance. Anecdotal evidence suggests that the clean-up costs associated with oil spills and hazardous waste sides might directly decrease earnings. In addition, the reputational damage resulting from environmental accidents can lead to customer boycotts which directly affect sales and profits. In contrast, strong environmental policies might largely be associated with intangible benefits, such as strong management skills, technological innovativeness and brand reputation that materialize slowly.

\subsection{Eco-Efficiency and Firm Value}

To examine empirically the relation between eco-efficiency and firm valuation, we estimate quarterly the following cross-sectional models:

$$
\begin{aligned}
& Q_{i t}=\alpha_{i}+\beta_{1} \text { Eco-Efficiency }_{i t}+\gamma_{i t} X_{i t}+\varepsilon_{i t}, \\
& Q_{\mathrm{it}}=\alpha_{i}+\beta_{0} \text { High Eco-Efficiency }{ }_{i t}+\beta_{1} \text { Low Eco-Efficiency }{ }_{i t}+\gamma_{i t} X_{i t}+\varepsilon_{i t},
\end{aligned}
$$

In model (3), $Q_{\text {it }}$ denotes Tobin's $q$ for firm i in quarter $\mathrm{t}$ and Eco-Efficiency ${ }_{\text {it }}$ represents the eco-efficiency rating of firm $i$ at t. $X_{i t}$ is a vector of control variables and $\gamma$ denotes a vector of coefficients. In model (4), we replace Eco-Efficiency $y_{i t}$ with two dummy variables that indicate whether firm $\mathrm{i}$ is eligible for inclusion in a high-ranked portfolio or a low-ranked portfolio similar to that of Derwall et al. (2005). The variable High Eco-Efficiency ${ }_{i t}$ (Low EcoEfficiency $y_{i t}$ ) is equal to unity if firm $i$ is rated five or six (zero or one), and zero otherwise.

Because we consider several model specifications, $X_{i t}$ contains permutations of the following candidate regressors: the firm's two-year sales growth, firm age, firms size measured by the logarithm of the book value of total assets, return on assets, R\&D spending, an interaction term between sales growth and R\&D spending, and a dummy variable for Nasdaq companies. From the 32 quarterly regressions, performed over the period January 1997 to December 2004, we compute Fama-MacBeth (1973) time-series averages and their respective $t$-statistics. We also allow for some variation in the dependent variable by repeating the 
TABLE 4

Eco-Efficiency and Firm Value (Tobin's q): Fama-MacBeth (1973) Regressions

The table reports the Fama-MacBeth (1973) time-series mean coefficient and the corresponding $t$-statistic (in parentheses). Note: Low Eco-Efficiency $=1$ if firm ranked $\leq 1$. High-Eco-Efficiency $=1$ if firm ranked $\geq 5$. To compute the difference between the coefficients, we subtract the Low Eco-Efficiency coefficient from the coefficient of the High Eco-Efficiency dummy. Ind.-adj. Q is the industry-adjusted Q. Sample period: 1997-Q1-2004-Q4. Significance at the 1\%, 5\%, and 10\% level is indicated by ${ }^{* * *}{ }^{* *}$, and ${ }^{*}$, respectively.

Fama-MacBeth Time-series Average Coefficients

\begin{tabular}{|c|c|c|c|c|c|c|c|c|}
\hline & \multicolumn{8}{|c|}{ Fama-MacBeth Time-series Average Coefficients } \\
\hline & \multicolumn{4}{|c|}{ Panel A: Equation (3) } & \multicolumn{4}{|c|}{ Panel B: Equation (4) } \\
\hline & $Q$ & Ind.Adj. $Q$ & $\log (Q)$ & Trimmed $Q$ & $Q$ & Ind.Adj. $Q$ & $\log (Q)$ & Trimmed $Q$ \\
\hline Intercept & $\begin{array}{l}1.59^{* * *} \\
(4.75)\end{array}$ & $\begin{array}{l}-0.78^{* *} \\
(-2.62)\end{array}$ & $\begin{array}{l}0.49^{* * *} \\
(4.51)\end{array}$ & $\begin{array}{l}1.55^{* * *} \\
(4.93)\end{array}$ & $\begin{array}{l}1.78^{* * *} \\
(4.89)\end{array}$ & $\begin{array}{l}-0.70^{* *} \\
(-2.21)\end{array}$ & $\begin{array}{l}0.57^{* * *} \\
(4.88)\end{array}$ & $\begin{array}{l}1.75^{* * *} \\
(5.06)\end{array}$ \\
\hline Eco-Efficiency & $\begin{array}{l}0.07^{* * *} \\
(5.46)\end{array}$ & $\begin{array}{l}0.05^{* * *} \\
(6.45)\end{array}$ & $\begin{array}{l}0.03^{* * *} \\
(8.16)\end{array}$ & $\begin{array}{l}0.07^{* * *} \\
(5.35)\end{array}$ & & & & \\
\hline Low Eco-Efficiency & & & & & $\begin{array}{l}-0.28^{* * *} \\
(-8.96)\end{array}$ & $\begin{array}{l}-0.21^{* * *} \\
(-7.55)\end{array}$ & $\begin{array}{l}-0.11^{* * *} \\
(-7.37)\end{array}$ & $\begin{array}{l}-0.29^{* * *} \\
(-8.59)\end{array}$ \\
\hline High Eco-Efficiency & & & & & $\begin{array}{l}0.10^{* *} \\
(2.09)\end{array}$ & $\begin{array}{c}6.02 \mathrm{E}-03 \\
(0.18)\end{array}$ & $\begin{array}{l}0.07^{* * *} \\
(6.89)\end{array}$ & $\begin{array}{l}0.10^{* *} \\
(2.28)\end{array}$ \\
\hline \multicolumn{2}{|c|}{ Difference: High-Low Eco-Efficiency } & & & & $\begin{array}{l}0.39^{* * *} \\
(5.87)\end{array}$ & $\begin{array}{l}0.22^{* * *} \\
(5.60)\end{array}$ & $\begin{array}{l}0.17^{* * *} \\
(8.53)\end{array}$ & $\begin{array}{l}0.39^{* * *} \\
(5.89)\end{array}$ \\
\hline \multicolumn{9}{|l|}{ Control variables: } \\
\hline Sales Growth & $\begin{array}{l}0.15^{* *} \\
(2.30)\end{array}$ & $\begin{array}{l}0.13^{* *} \\
(2.10)\end{array}$ & $\begin{array}{c}2.78 \mathrm{E}-03 \\
(0.21)\end{array}$ & $\begin{array}{l}0.13^{*} \\
(2.03)\end{array}$ & $\begin{array}{l}0.15^{* *} \\
(2.29)\end{array}$ & $\begin{array}{l}0.13^{* *} \\
(2.07)\end{array}$ & $\begin{array}{c}2.07 \mathrm{E}-03 \\
(0.15)\end{array}$ & $\begin{array}{l}0.13^{* *} \\
(2.04)\end{array}$ \\
\hline Firm Age & $\begin{array}{l}-0.02^{* *} \\
(-2.28)\end{array}$ & $\begin{array}{l}-0.02^{*} \\
(-1.73)\end{array}$ & $\begin{array}{c}-8.72 \mathrm{E}-03^{* * *} \\
(-3.30)\end{array}$ & $\begin{array}{l}-0.02^{* *} \\
(-2.37)\end{array}$ & $\begin{array}{l}-0.02^{*} \\
(-2.00)\end{array}$ & $\begin{array}{l}-0.02 \\
(-1.46)\end{array}$ & $\begin{array}{l}-0.01^{* * *} \\
(-3.10)\end{array}$ & $\begin{array}{l}-0.02^{* *} \\
(-2.06)\end{array}$ \\
\hline $\log$ (Book Value of Assets) & $\begin{array}{l}-0.10^{* * *} \\
(-4.07)\end{array}$ & $\begin{array}{c}1.85 \mathrm{E}-03 \\
(0.10)\end{array}$ & $\begin{array}{l}-0.05^{* * *} \\
(-6.48)\end{array}$ & $\begin{array}{l}-0.09^{* * *} \\
(-3.86)\end{array}$ & $\begin{array}{l}-0.09^{* * *} \\
(-3.93)\end{array}$ & $\begin{array}{c}8.73 \mathrm{E}-03 \\
(0.48)\end{array}$ & $\begin{array}{l}-0.05^{* * *} \\
(-6.40)\end{array}$ & $\begin{array}{l}-0.09^{* * *} \\
(-3.73)\end{array}$ \\
\hline Return on Assets & $\begin{array}{c}38.89^{* * * *} \\
(17.65) \\
\end{array}$ & $\begin{array}{l}30.94^{* * *} \\
(19.02)\end{array}$ & $\begin{array}{l}13.98^{* * *} \\
(22.91)\end{array}$ & $\begin{array}{l}37.03^{* * *} \\
(16.76)\end{array}$ & $\begin{array}{l}38.85^{* * *} \\
(17.55)\end{array}$ & $\begin{array}{l}31.00^{* * *} \\
(18.88)\end{array}$ & $\begin{array}{l}13.98^{* * *} \\
(22.58)\end{array}$ & $\begin{array}{l}36.99^{* * *} \\
(16.61)\end{array}$ \\
\hline
\end{tabular}


estimation of (3) and (4) using, respectively, an industry-adjusted $Q$ ( $Q$ minus the industry median $Q), Q$ in logs, and a trimmed $Q$ as a dependent variable. Trimming mitigates the effect of potential outliers in Tobin's $q$. We adopt the trimming approach of Collins et al. (1997) and remove observations using the 0.995 percentile and the 0.005 percentile as upper and lower boundaries.

Table 4 shows the results for the main model specifications. Panel A of Table 4 reports the results of estimating equation (3). The first column of this panel reports the results of a regression based on a standard, unmodified $Q$. The additional columns present the results of using, respectively, industry-adjusted $Q$ ( $Q$ minus the industry median $Q), Q$ in logs, and trimmed $Q$. Taken as a whole, regardless of the choice of the dependent variable, the coefficients on most control variables (sales growth, size and ROA and firm age) are significant and carry signs that are consistent with a priori expectations and with previous research. The only exceptions are the age variable, for which the coefficient weakens once we use industry-adjusted Tobin's $q$, and the sales growth variable, which becomes insignificant when we take the logarithm of $Q$ as a dependent variable.

The observation most relevant to our study is that under all scenarios, the coefficient on Eco-Efficiency ${ }_{i t}$ is positive and statistically significant at the 1 percent level. Our estimate of the eco-efficiency coefficient $\left(\beta_{1}\right)$ in equation (3) is approximately 0.07 when $Q$ is the dependent variable. The coefficient decreases due to rescaling when $Q$ is taken in $\log$, but remains highly significant. Furthermore, we note that neither industry adjustment nor trimming of Tobin's $q$ affects the coefficient estimates substantially. The latter observation is important because it suggests our results are not driven by outliers arising from, for instance, the stock market crash of 2000. Overall, these parameter estimates support $\mathrm{H}_{2 b}$.

Panel B of Table 4, adds to understanding the positive association between ecoefficiency and $Q$. The panel reports the outcomes of replacing Eco-Efficiency ${ }_{i t}$ with the dummy variables High Eco-Efficiency ${ }_{i t}$ and Low Eco-Efficiency ${ }_{i t}$ (equation (4)). The results indicate a slightly asymmetric relationship between eco-efficiency and $Q$ : The negative coefficient on the Low Eco-Efficiency dummy is larger in magnitude than the positive coefficient on the High Eco-efficiency dummy. However, evidence of asymmetry varies across the specifications and should be interpreted with care. Most important to our research question is the fact that the most eco-efficient firms have a significantly higher valuation than their least eco-efficient counterparts. 
To evaluate the robustness of the relationships further, we estimate additional models that include different sets of control variables. Table 5 presents the outcomes for these alternative specifications. For reasons of comparison, we import the initial results pertaining to equations (3) and (4) from the previous table. In line with Konar and Cohen (2001) two alternative models augment the first set of control variables by R\&D expenditure. In the second model, we also add an interaction term between sales growth and R\&D expenditure. We note that the inclusion of R\&D spending decreases our sample size substantially, since this information was not available for a large number of firms. The last alternative specification expands the first model by the Nasdaq dummy.

In panel $\mathrm{A}$, the results show that even in the presence of additional control variables, the sensitivity of $Q$ with respect to the eco-efficiency score remains positive and significant at the 1 percent level. The coefficient estimate of Eco-Efficiency decreases somewhat once we include R\&D spending as an additional control. However, because limited availability of (cross-sectional) R\&D data induces a small sample problem, the results we find under the third and fourth set of control variables should be interpreted with caution.

The results of replacing Eco-Efficiency it with High Eco-Efficiency it and Low EcoEfficiency $_{\text {it }}$ are given in Panel B of Table 5. Again, the evidence supports $\mathrm{H}_{2 \mathrm{~b}}$. After the inclusion of the additional control variables, the asymmetry weakens. Independent of the set of control variables, we find a significant valuation differential between the most eco-efficient and the least eco-efficient firms.

In order to assess the economic significance of eco-efficiency, we can estimate how much a firm would enjoy an increase in valuation resulting from a unit increase in ecoefficiency ranking. Table 4, panel A, suggests that the impact of a one-point increase in ecoefficiency ranking on Tobin's $q$ amounts to 0.07 , ceteris paribus, which is approximately 3.2 percent of the average $Q$ we observe for all firms in the sample. To address the asymmetrical influence we estimate how much loss in $Q$ a firm in the reference group would prevent by avoiding a low eco-efficiency ranking. Panel B suggests that the loss avoidance varies from 9 percent to 13 percent of the sample-average $Q$, depending on the choice of model. The gain from receiving a high eco-efficiency rating is in the range of almost 0 to 7 percent. 
TABLE 5

\section{Eco-Efficiency and Firm Value: Robustness Checks}

The table reports the Fama-MacBeth (1973) time-series mean coefficient and the corresponding $t$-statistic (in parentheses). Note: Low Eco-Efficiency $=1$ if firm ranked $\leq 1$. High-Eco-Efficiency $=1$ if firm ranked $\geq 5$. To compute the difference between the coefficients, we subtract the Low Eco-Efficiency coefficient from the coefficient of the High Eco-Efficiency dummy. Ind.-adj. Q is the industry-adjusted Q. Sample period: $1997-\mathrm{Q} 1-2004-\mathrm{Q} 4$. Significance at the $1 \%, 5 \%$, and $10 \%$ level is indicated by ${ }^{* * *},{ }^{* *}$, and ${ }^{*}$, respectively.

\begin{tabular}{|c|c|c|c|c|c|c|c|c|}
\hline & \multicolumn{8}{|c|}{ Fama-MacBeth Time-series Average Coefficients } \\
\hline & \multirow[b]{2}{*}{$Q$} & \multicolumn{3}{|c|}{ Panel A: Equation (3) } & \multirow[b]{2}{*}{$Q$} & \multicolumn{3}{|c|}{ Panel B: Equation (4) } \\
\hline & & $Q$ & $Q$ & $Q$ & & $Q$ & $Q$ & $Q$ \\
\hline Intercept & $\begin{array}{l}1.59^{* * *} \\
(4.75)\end{array}$ & $\begin{array}{c}0.62^{*} \\
(2.02)\end{array}$ & $\begin{array}{c}0.53^{*} \\
(1.83)\end{array}$ & $\begin{array}{l}0.65^{* *} \\
(2.55)\end{array}$ & $\begin{array}{l}1.78^{* * *} \\
(4.89)\end{array}$ & $\begin{array}{l}0.72^{* *} \\
(2.27)\end{array}$ & $\begin{array}{l}0.63^{* *} \\
(2.09)\end{array}$ & $\begin{array}{l}0.78^{* * *} \\
(2.81)\end{array}$ \\
\hline Eco-Efficiency & $\begin{array}{l}0.07^{* * *} \\
(5.46)\end{array}$ & $\begin{array}{l}0.04^{* * *} \\
(4.45)\end{array}$ & $\begin{array}{l}0.04^{* * *} \\
(4.69)\end{array}$ & $\begin{array}{l}0.05^{* * *} \\
(4.95)\end{array}$ & & & & \\
\hline Low Eco-Efficiency & & & & & $\begin{array}{l}-0.28^{* * *} \\
(-8.96)\end{array}$ & $\begin{array}{l}-0.12^{*} \\
(-1.98)\end{array}$ & $\begin{array}{l}-0.13^{* * *} \\
(-2.78)\end{array}$ & $\begin{array}{l}-0.17^{* * *} \\
(-5.23)\end{array}$ \\
\hline High Eco-Efficiency & & & & & $\begin{array}{l}0.10^{* *} \\
(2.09)\end{array}$ & $\begin{array}{c}0.13^{*} \\
(1.72)\end{array}$ & $\begin{array}{c}0.09 \\
(1.56)\end{array}$ & $\begin{array}{l}0.12^{* *} \\
(2.32)\end{array}$ \\
\hline \multicolumn{2}{|c|}{ Difference: High-Low Eco-Efficiency } & & & & $\begin{array}{c}0.39^{* * *} \\
(5.87)\end{array}$ & $\begin{array}{l}0.25^{* * *} \\
(4.73)\end{array}$ & $\begin{array}{l}0.22^{* * *} \\
(4.74)\end{array}$ & $\begin{array}{l}0.29^{* * *} \\
(5.22)\end{array}$ \\
\hline \multicolumn{9}{|l|}{ Control variables: } \\
\hline Sales Growth & $\begin{array}{l}0.15^{* *} \\
(2.30)\end{array}$ & $\begin{array}{c}0.67^{* * *} \\
(3.61)\end{array}$ & $\begin{array}{c}-0.04 \\
(-0.31)\end{array}$ & $\begin{array}{c}0.09^{*} \\
(1.92)\end{array}$ & $\begin{array}{l}0.15^{* *} \\
(2.29)\end{array}$ & $\begin{array}{c}0.66^{* * *} \\
(3.51)\end{array}$ & $\begin{array}{c}-0.03 \\
(-0.22)\end{array}$ & $\begin{array}{c}0.09^{*} \\
(1.88)\end{array}$ \\
\hline Firm Age & $\begin{array}{l}-0.02^{* *} \\
(-2.28)\end{array}$ & $\begin{array}{l}-0.01 \\
(-0.91)\end{array}$ & $\begin{array}{l}-0.01 \\
(-0.89)\end{array}$ & $\begin{array}{c}-4.45 \mathrm{E}-03 \\
(-0.55)\end{array}$ & $\begin{array}{l}-0.02^{*} \\
(-2.00)\end{array}$ & $\begin{array}{l}-0.01 \\
(-0.71)\end{array}$ & $\begin{array}{l}-0.01 \\
(-0.70)\end{array}$ & $\begin{array}{c}-3.38 \mathrm{E}-03 \\
(-0.40)\end{array}$ \\
\hline $\log ($ Book Value of Assets $)$ & $\begin{array}{l}-0.10^{* * *} \\
(-4.07)\end{array}$ & $\begin{array}{l}-0.05^{* *} \\
(-2.34)\end{array}$ & $\begin{array}{c}-0.03 \\
(-1.38)\end{array}$ & $\begin{array}{c}-0.03 \\
(-1.60)\end{array}$ & $\begin{array}{l}-0.09^{* * *} \\
(-3.93)\end{array}$ & $\begin{array}{l}-0.05^{* *} \\
(-2.36)\end{array}$ & $\begin{array}{c}-0.03 \\
(-1.42)\end{array}$ & $\begin{array}{c}-0.03 \\
(-1.46)\end{array}$ \\
\hline Return on Assets & $\begin{array}{c}38.89^{* * * * *} \\
(17.65)\end{array}$ & $\begin{array}{l}41.11^{* * *} \\
(26.50)\end{array}$ & $\begin{array}{l}41.18^{* * *} \\
(23.96)\end{array}$ & $\begin{array}{c}38.41^{* * *} \\
(20.05)\end{array}$ & $\begin{array}{c}38.85^{* * *} \\
(17.55)\end{array}$ & $\begin{array}{c}41.12^{* * *} \\
(26.28)\end{array}$ & $\begin{array}{c}41.22^{* * *} \\
(24.05)\end{array}$ & $\begin{array}{l}38.43^{* * *} \\
(20.03)\end{array}$ \\
\hline Research \& Development (R\&D) & & $\begin{array}{l}9.48^{* * *} \\
(7.37)\end{array}$ & $\begin{array}{l}7.91^{* * *} \\
(11.27)\end{array}$ & & & $\begin{array}{c}9.62^{* * *} \\
(7.16)\end{array}$ & $\begin{array}{l}8.05^{* * *} \\
(10.95)\end{array}$ & \\
\hline R\&D*Sales Growth & & & $\begin{array}{c}10.66^{* * *} \\
(4.23)\end{array}$ & & & & $\begin{array}{c}10.30^{* * * *} \\
(4.21)\end{array}$ & \\
\hline Nasdaq Dummy & & & & $\begin{array}{l}1.61^{* * *} \\
(6.45)\end{array}$ & & & & $\begin{array}{l}1.60^{* * *} \\
(6.18) \\
\end{array}$ \\
\hline
\end{tabular}




\subsection{Eco-Efficiency and Firm Value: Tests for a Time-Varying Market Response}

A positive (though potentially asymmetrical) relation between eco-efficiency and firm value is consistent with the notion that eco-efficiency is a "priced" factor, i.e., that investors drive up the value of environmental leaders by lowering their expected stock return and their costof-capital. However, up to this point, the association between Tobin's $q$ and eco-efficiency does not reconcile with the evidence by Derwall et al. (2005) that eco-efficient stock portfolios have realized anomalously high risk-adjusted returns relative to their least ecoefficient counterparts. Their results raise the possibility that the market has undervalued ecoefficient firms relative to less eco-efficient companies. In an equilibrium setting, the expected returns on a group of eco-efficient companies can be lower than the returns on a group of less eco-efficient companies because eco-efficient firms are deemed less risky. After adjustment for these risk differences, there should be no abnormal difference in return. However, under the hypothesis that the market reacts to eco-efficiency with a drift, firms can be under- or overvalued and risk-adjusted portfolio returns can be anomalous.

The Derwall et al. (2005) zero investment portfolio of the most eco-efficient firms versus the least eco-efficient firms earns an average abnormal return in the order of 2.2 percent to 8.6 percent per annum depending on the portfolio construction method and the performance attribution model used. By examining the sensitivity of Tobin's $q$ to corporate eco-efficiency under each separate cross-sectional regression, we can investigate whether the superior stock performance associated with eco-efficiency translates into a higher valuation over time for eco-efficient companies relative to their eco-inefficient counterparts. We could expect the abnormal returns associated with eco-efficient firms to induce an upward trend in their Tobin's $q$ values.

To shed more light on the nature of the large return differential documented in Derwall et al. (2005), we now exploit the attractive features of the Tobin's $q$ measure and of the FamaMacBeth (1973) regression technique. First, we divide our sample period into two subperiods. Table 6, which reports regression results for Tobin's $q$ broken up into two subsamples, confirms our expectations. The table shows time-series average coefficients for the 1997-2000 and 2001-2004 periods, respectively. The subsample results indicate a strong time variation in the difference between the coefficients on High Eco-Efficiency and Low Eco-Efficiency. In the later subperiod, eco-efficient companies were selling at a premium more than twice as large as that in the earlier subperiod, consistent with a scenario that investors have changed their view on the value of eco-efficiency. 
TABLE 6

Eco-Efficiency and Firm Value: Subperiod Results

Reported are the time-series mean coefficients and the $t$-statistics (in parentheses) of the difference between High Eco-Efficiency and Low Eco-Efficiency based on equation (4). Low Eco-Efficiency $=1$ if firm ranked $\leq$ 1. High Eco-Efficiency $=1$ if firm ranked $\geq 5$. To compute the difference between the coefficients, we subtract the Low Eco-Efficiency coefficient from the coefficient of the High Eco-Efficiency dummy. The subperiods are 1997-Q1 to 2000-Q4 and 2001-Q1 to 2004-Q4. Significance at the 1\%, 5\%, and 10\% level is indicated by ${ }^{* * *}{ }^{* *}$, and ${ }^{*}$, respectively.

\begin{tabular}{|c|c|c|c|c|}
\hline & \multicolumn{4}{|c|}{ Fama-MacBeth Time-series Average Coefficients } \\
\hline & $Q$ & Ind.Adj. $Q$ & $\log (Q)$ & Trimmed $Q$ \\
\hline \multicolumn{5}{|l|}{ Subperiod 1} \\
\hline Difference High-Low Eco-Efficiency & $\begin{array}{l}0.20^{*} \\
(1.82)\end{array}$ & $\begin{array}{l}0.13^{*} \\
(1.93)\end{array}$ & $\begin{array}{l}0.08^{* * *} \\
(3.61)\end{array}$ & $\begin{array}{l}0.22^{*} \\
(1.90)\end{array}$ \\
\hline \multicolumn{5}{|l|}{ Subperiod 2} \\
\hline Difference High-Low Eco-Efficiency & $\begin{array}{l}0.57^{* * *} \\
(15.19)\end{array}$ & $\begin{array}{l}0.31^{* * *} \\
(10.05)\end{array}$ & $\begin{array}{l}0.26^{* * *} \\
(24.89)\end{array}$ & $\begin{array}{l}0.56^{* * *} \\
(15.84)\end{array}$ \\
\hline \multicolumn{5}{|l|}{ Complete Period } \\
\hline Difference High-Low Eco-Efficiency & $\begin{array}{l}0.39^{* * *} \\
(5.87)\end{array}$ & $\begin{array}{l}0.22^{* * *} \\
(5.60)\end{array}$ & $\begin{array}{l}0.17^{* * *} \\
(8.53)\end{array}$ & $\begin{array}{l}0.39^{* * *} \\
(5.89)\end{array}$ \\
\hline
\end{tabular}

In Table 7, we express the time-varying market response to eco-efficiency by estimating a trend in the relation between eco-efficiency and Tobin's $q$. More specifically, we perform a time-series regression using the differences between the quarterly estimates of the crosssectional coefficients on the two dummy variables $\left(\beta_{0}\right.$ High Eco-Efficiency - $\beta_{1}$ Low EcoEfficiency) as the dependent variable and time as the regressor. To account for potential autocorrelation, we compute $t$-statistics based on Newey-West (1987) autocorrelation-robust standard errors ${ }^{3}$. Table 7, Panel A, reports the annual increases in valuation differential based on the specifications described in Table 4, whereas Table 7, Panel B, presents those corresponding to Table 5. Independent of the specification, we find that the trend in valuation is significantly different from zero. The intercept combined with the time coefficient demonstrate that although eco-efficient firms were not selling at a relative premium at the beginning of the sample period, the premium increases strongly over time. Equally important is the economic interpretation of the trend. Our estimates of the trend range between 2.8 percent and 5 percent. These percentages resemble the abnormal returns outlined by Derwall et al. (2005).

\footnotetext{
${ }^{3}$ Since Newey-West (1987) standard errors might be overstated for small samples, we compute in addition conventional standard errors. Our findings are similar and available upon request from the authors.
} 
The subperiod results as well as the upward-sloping trend line support $\mathrm{H}_{2 \mathrm{c}}$. The time-varying pattern may indicate that the value of eco-efficiency is not well understood by capital markets. Although finding that environmental information is priced gradually seems to contradict the notion that markets are efficient, our study is not the first to show that some information about companies is slowly incorporated into stock prices. For example, there is evidence that stock repurchases (Ikenberry et al., 1995) and dividend omissions (e.g., Michaely et al., 1995), all of which are arguably more concrete events than environmental events, have a post-event drift.

Our results raise the idea that investors can exploit temporary mispricing of corporate environmental performance criteria. At the very least, our results suggest the market shows increased interest in information about the environmental management of the firm.

TABLE 7

Trend in Eco-Efficiency Premium

Based on the difference between $\beta_{0}$ and $\beta_{1}$ for each quarterly estimation of equation (4): $Q_{i t}=\alpha_{i}+\beta_{0}$ High EcoEfficiency $_{\text {it }}+\beta_{1}$ Low Eco-Efficiency ${ }_{i t}+\gamma_{i t} X_{i t}+\varepsilon_{i t}$, we estimate the time trend: $\beta_{0}-\beta_{1}=\alpha+\beta_{2}$ time $_{t}+\varepsilon_{t}$, where time ranges from 1 to 32 . We compute Newey-West (1987) adjusted standard errors. Panel A reports the coefficients of time and the corresponding t-statistics for all specifications shown in Table 4. Panel B shows the time trend coefficient and t-statistics for all estimations presented in Table 5. Significance at the $1 \%, 5 \%$, and $10 \%$ level is indicated by ${ }^{* * * * *},{ }^{*}$, and ${ }^{*}$, respectively.

Panel A

\begin{tabular}{ccc}
\hline & Intercept & Annual \% Trend \\
\hline$Q$ & -0.02 & $4.32^{* * *}$ \\
& $(-0.15)$ & $(3.56)$ \\
Ind.Adj. $Q$ & -0.01 & $2.42^{* * *}$ \\
& $(-0.14)$ & $(4.47)$ \\
$\log (Q)$ & 0.01 & $3.83^{* * *}$ \\
& $(0.36)$ & $(5.65)$ \\
Trimmed $Q$ & -0.01 & $4.30^{* * *}$ \\
& $(-0.10)$ & $(3.61)$ \\
\hline
\end{tabular}

Panel B

\begin{tabular}{ccc}
\hline & Intercept & $\begin{array}{c}\text { Annual \% } \\
\text { Trend }\end{array}$ \\
\hline$Q$ & -0.02 & $4.98^{* * *}$ \\
& $(-0.15)$ & $(3.56)$ \\
$Q$ & -0.07 & $3.34^{* * *}$ \\
& $(-0.81)$ & $(4.28)$ \\
$Q$ & -0.08 & $3.16^{* * *}$ \\
& $(-1.45)$ & $(5.18)$ \\
$Q$ & -0.08 & $3.93^{* * *}$ \\
& $(-1.13)$ & $(4.16)$ \\
\hline
\end{tabular}




\section{Conclusion}

Can corporate environmental management be aligned with the economic objectives of a firm? This study provides new answers to this question. Focusing on the concept of eco-efficiency, we perform an extensive analysis on the relation between corporate eco-efficiency and several dimensions of financial performance. Using a large database containing monthly scores for the period December 1996 - December 2004, we find evidence suggesting that the virtues of a strong corporate eco-efficiency policy can be significant from a financial perspective.

Our study points to a positive and slightly asymmetric relation between eco-efficiency and operating performance. Firms that are deemed eco-efficient have only a slightly superior return on assets than the control group. The least eco-efficient firms show strong operational underperformance. Overall, our findings strongly reject the notion expressed by CSR skeptics, that the benefits of adopting a strong environmental policy are unlikely to outweigh the costs.

Our study provides new evidence of a positive and time-varying relation between ecoefficiency and firm valuation as measured by Tobin's $q$. An exploration into the time-varying sensitivities of firm value with respect to the eco-efficiency scores shows that environmental winner companies initially did not trade at a premium relative to losers. Over time, the valuation differential between winners and losers widened substantially. The observed upward trend in relative firm valuation offers an explanation for recent evidence by Derwall et al. (2005). This trend suggests that the shares of most eco-efficient firms relative to the least eco-efficient firms were initially undervalued but later experienced an upward price correction. At the very least, Tobin's $q$ regression results suggest, that these days, the market assigns more value-relevance to environmental information about firms.

We believe the results of this paper have implications for both managers and investors. Evidently, managers have little reason to worry that an environmental policy conflicts with the company's primary financial objectives. Investors may interpret our results as evidence that corporate environmental performance is a potential source of information that helps them generate superior excess returns. As for these excess returns, an important avenue for further research would be to look at the endurance of the observed upward trend in the valuation differential between environmental winners and losers.

Hence, although this study asserts that the observed patterns in Tobin's $q$ reflect a correction for undervaluation of eco-efficient companies, it is forced to leave some important questions unexplained. Will these patterns persist in the future? What does this imply about future shareholder returns? 


\section{REFERENCES}

Alexander, G. J., Buchholz, R. A., 1978. Corporate Social Responsibility and Stock Market Performance. Academy of Management Journal 21(3), 479-486.

Barber, B.M., Lyon, J.D., 1996. Detecting Abnormal Operating Performance: The Empirical Power and Specification of Test Statistics. Journal of Financial Economics 41, 359399

Bowman, E., Haire, M., 1975. A Strategic Posture Towards CSR. California Management Review 18(2), 49-58.

Cohen, M.A., Fenn, S.A., Konar, S., 1997. Environmental and Financial Performance: Are They Related? Working Paper.

Collins, D.W., Maydew, E.L., Weiss, I.S., 1997. Changes in the Value-relevance of Earnings and Book Values over the Past Forty Years. Journal of Accounting and Economics 24, 39-67.

Chen, K.H., Metcalf, R.W., 1980. The Relationship Between Pollution Control Record and Financial Indicators Revisited. The Accounting Review 55(1), 168-177.

Chung, K.H., Pruitt, S., 1994. A Simple Approximation of Tobin's q. Financial Management $23,70-74$.

Davis, K., 1973. The Case for and Against Business Assumption of Social Responsibilities. Academy of Management Journal 16, 312-322.

Derwall, J., Guenster, N., Bauer, R., Koedijk, K., 2005. The Eco-Efficiency Premium Puzzle. Financial Analysts Journal 61(2), 51-63.

Dowell, G.A., Hart, S., Yeung, B., 2000. Do Corporate Global Environmental Standards Create or Destroy Market Value? Management Science 46(8), 1059-1074.

Fama, E.F., MacBeth, J. D., 1973. Risk, Return and Equilibrium: Empirical Tests. Journal of Political Economy 81, 607-636.

Fama, E.F., French, K.R., 1993. Common Risk Factors in the Returns on Stocks and Bonds. Journal of Financial Economics 33, 3-56.

Fama, E.F., French, K.R., 1998. Value versus Growth: The International Evidence. Journal of Finance 53(6), 1975-1999.

Fombrun, C.J., Gardberg, N.A., Barnett, M.L., 2000. Opportunity Platforms and Safety Nets: Corporate Citizenship and Reputational Risk. Business and Society Review 105(1), 85-106.

Freedman, M., Jaggi, B., 1988. An Analysis of the Association between Pollution Disclosure and Economic Performance. Accounting, Auditing and Accountability 1(2), 43-58. 
Friedman, M., 1962. Capitalism and Freedom. University of Chicago Press. Chicago

Griffin, J.J., Mahon, J.F., 1997. The Corporate Social Performance and Corporate Financial Performance Debate. Twenty-Five Years of Incomparable Research. Business \& Society 36(1), 5-31.

Gompers, P., Ishii, M., Metrick, A., 2003. Corporate Governance and Equity Returns, The Quarterly Journal of Economics 118(1), 107-155

Hamilton, J.T. 1995. Pollution as News: Media and Stock Market Reactions to the Toxics Release Inventory Data. Journal of Environmental Economics and Management 28, 98-113.

Hamilton, S., Jo, H., Statman, M., 1993. Doing Well While Doing Good? The Investment Performance of Socially Responsible Mutual Funds. Financial Analysts Journal 49(6), $62-66$.

Hart, S.L., Ahuja, G., 1996. Does It Pay To Be Green? An Empirical Examination of the Relationship between Emission Reduction and Firm Performance. Business Strategy and the Environment 5, 30-37.

Henderson, D., 2002. Misguided Virtue: False Notions of Corporate Social Responsibility. Institute of Economic Affairs, London.

Hillman, A.J., Keim, G.D., 2001. Shareholder Value, Stakeholder Management, and Social Issues: What's the Bottom Line? Strategic Management Journal 22, 125-139.

Hirsch, B.T., 1991. Union Coverage and Profitability among U.S. Firms. Review of Economics and Statistics 73 (1), 69-77.

Ikenberry, D., Lakonishok, J., Vermaelen, T., 1995. Market Underreaction to Open Market Share Repurchases. Journal of Financial Economics 39(2), 181-208.

Kaplan S.N., Zingales, L., 1997. Do Investment-Cash Flow Sensitivities Provide Useful Measures of Financing Constraints? Quarterly Journal of Economics 112, 169-215.

King, A., Lenox, M. 2002. Exploring the Locus of Profitable Pollution Reduction. Management Science 48(2), 289-299.

Klassen, R.D., McLaughlin, C.P., 1996. The Impact of Environmental Management on Firm Performance. Management Science 42(8), 1199-1214.

Konar, S, Cohen, M.A., 2001. Does the Market Value Environmental Performance? Review of Economics and Statistics 83(2), 281-289.

Mahapatra, S., 1984. Investor Reaction to a Corporate Social Accounting. Journal of Business Finance and Accounting 11(1), 29-40. 
McGuire, J. B., Sundgren, A., Schneeweis, T., 1988. Corporate Social Responsibility and Firm Financial Performance. Academy of Management Journal 31(4), 854-872.

Michaely, R., R. Thaler, K. Womack., 1995. Price Reactions to Dividend Initiations and Omissions. Journal of Finance 50(2), 573-608.

Moskowitz, M., 1972. Choosing Socially Responsible Stocks. Business and Society Review $1,71-75$.

Narver, J.C., 1971. Rational Management Response to External Effects. Academy of Management Journal 14(1), 99-115.

Newey, W.K., West, K.D., 1987. A Simple, Positive Semi-Definite Heteroskedasticity and Autocorrelation Consistent Variance Covariance Matrix. Econometrica 55(3), 703708.

Perfect, S.B., Wiles, K.W., 1994. Alternative Constructions of Tobin's q: An Empirical Comparison. Journal of Empirical Finance 1(3), 313-341.

Porter, M.E., van der Linde, C., 1995. Green and Competitive. Ending the Stalemate. Harvard Business Review 73(5), 120-135.

Russo, M.V., Fouts, P.A., 1997. A Resource-Based Perspective on Corporate Environmental Performance and Profitability. Academy of Management Journal 40(3), 534-559.

Shane, P.B., Spicer, B.H., 1983. Market Response to Environmental Information Produced Outside the Firm. The Accounting Review 58(3), 521-285.

Shrivastava, P., 1995. Ecocentric Management for a Risk Society. Academy of Management Review 20, 118-137.

Social Investment Forum. 2003. 2003 Report on Socially Responsible Investing Trends in the United States. http:// www.socialinvestment.org

Spicer, B. H., 1978. Investors, Corporate Social Performance and Information Disclosure: an Empirical Study. The Accounting Review 53(4), 781-796.

Thomas, A., 2001. Corporate Environmental Policy and Abnormal Stock Price Returns: an Empirical Investigation. Business Strategy and The Environment 10, 125-134.

Turban, D.B., Greening, D.W., 1996. Corporate Social Performance and Organizational Attractiveness to Prospective Employees. Academy of Management Journal 40(3), 658-672.

Ullman, A.E., 1985. Data in Search of a Theory: A Critical Examination of the Relationships Among Social Performance, Social Disclosure, and Economic Performance of U.S. Firms. Academy of Management Review 10(3), 540-557. 
Vandermerwe, S., Oliff, M.D., 1990. Customers Drive Corporations Green. Long Range Planning 23(6), 3-9.

Waddock, S. A., Graves, S. B., 1997. The Corporate Social Performance-Financial Performance Link. Strategic Management Journal 18(4), 303-319.

Walley, N., Whitehead, B., 1994. It's Not Easy Being Green. Harvard Business Review 72(3), 46-52.

White, M.A. 1996. Corporate Environmental Performance and Shareholder Value. Working Paper WHI002. McIntire School of Commerce.

Ziegler, A., Rennings, K Schröder, M., 2002. The Effect of Environmental and Social Performance on the Shareholder Value of European Stock Corporations. Working Paper. Centre for European Economic Research (ZEW). 